\title{
The stridulatory setae of Acanthoscurria suina (Araneae, Theraphosidae) and their possible role in sexual communication: an experimental approach
}

\author{
Fernando Pérez-Miles ${ }^{1,2}$, Laura Montes de Oca ${ }^{1}$, Rodrigo Postiglioni ${ }^{1,2}$ \& Fernando G. Costa ${ }^{2}$ \\ 1. Sección Entomología, Facultad de Ciencias, Iguá 4225, 11400 Montevideo, Uruguay. \\ 2. Laboratorio de Etología, Ecología y Evolución, IIBCE, Av. Italia 3318, 11600 Montevideo, Uruguay.
}

\begin{abstract}
Specialized setae placed on proximal segments of appendages in tarantulas have been related to sound production (stridulation), used in defense or sexual communication. The surface structure of called stridulatory setae of Acanthoscurria suina Pocock, 1903 was studied by SEM. Three morphological types of setae were recognized and at least two of them could be involved in stridulation. Their role in sexual communication was tested by experimental removal. Our results showed no differences in the sexual success between the setaeless and control individuals. Consequently, a defensive function for stridulatory setae seems to be more likely than a sexual function.
\end{abstract}

KEYWORDS. Stridulatory setae, Tarantula spiders, Acanthoscurria suina, behavior.

\begin{abstract}
RESUMEN. Las setas estridulatorias de Acanthoscurria suina (Araneae, Theraphosidae) y su posible rol en la comunicación sexual: una aproximación experimental. Las setas especializadas que las tarántulas presentan en los segmentos proximales de los apéndices han sido relacionadas con la producción de sonidos (estridulación), utilizados en defensa o comunicación sexual. La estructura superficial de las setas llamadas estridulatorias en Acanthoscurria suina Pocock, 1903 fue estudiada mediante microscopía electrónica de barrido. Tres patrones morfológicos de setas fueron reconocidos y al menos dos de ellos podrían estar involucrados en la estridulación. Su rol en la comunicación sexual fue estudiado mediante remoción experimental. Los resultados no mostraron diferencias en el éxito sexual entre individuos sin setas e individuos control. Consecuentemente, parece más probable una función defensiva que sexual para dichas setas.
\end{abstract}

PALABRAS CLAVE. Setas estridulatorias, tarantulas, Acanthoscurria suina, comportamiento.

Since early times the sound production by stridulation in spiders has attracted the attention of arachnologists (Рососк, $1895 \mathrm{a}, \mathrm{b})$. As in insects, these organs consist of two opposite surfaces which rub one against the other, which are located in several parts of body of the spider (Uetz \& Stratton, 1982). LEGEndRe (1963) attributed to Westring (1843) the first description of a feature with such probable function in Theridiidae, but the first audible sound was reported for spider by WoOd-MASON (1876) for the Indian theraphosid Chilobrachys stridulans (Wood-Mason, 1875). Up to now, several features were described and classified in tarantulas as stridulatory organs (for revisions see Chrysanthus, 1953; Legendre, 1963; Uetz \& Stratton, 1982). In fact, these organs were widely used in the systematics of Theraphosidae (Рососк, 1895 a, b, 1897, 1899; Simon, 1903; PéreZ-Miles et al., 1996; SCHMIDT, 1999, 2000). The tarantulas present high diversity of such features among the spiders, but the evidence of sound or signal production of this organs is very scarce, as well as its role in communication (but see MARSHALl et al., 1995). As far as we know, two hypothetical functions of the signals were proposed for spiders: 1) in defensive behavior and 2) in sexual communication (LEGENDRE, 1963; UetZ \& Stratton, 1982; Marshall et al., 1995).

Acanthoscurria suina Pocock, 1903 is a medium to large-sized tarantula, which is frequent in meadows and hilly zones of Argentina and Uruguay. This species has specialized setae on the retrolateral face of palpal trochanter and in the prolateral face of trochanter I (Schiapelli \& Gerschman, 1964). The placement of this organ corresponds to a variant of type "e" in the classification of LEGENDRE (1963) or type IV of SCHMIDT (2000). Males, females and large juveniles of this species have these setae. The sexual communication in this species seems to be mainly seismic, without sound components at medium or long distances (QUiRICI \& COSTA, 2005). Unusually, the receptive female responds to male courtship displaying leg tapping against the substrate (Quirici \& Costa, 2003, 2005). No audible (airborne) sound was perceived by the human hear from this species. However the possible role of these setae in the production of such seismic or substratum-coupled signals is unknown.

Considering that $A$. suina courting males perform continuous palpal drumming near the burrow entrance (QUIRICI \& COSTA, 2005), our starting hypothesis was that these stridulatory organs could produce signals used in sexual communication at short distances.

This study aims to describe the setae called stridulatory bristles, and to test the possible function of these organs in the sexual communication of A. suina by means of experimental removal of stridulatory setae, in trials of sexual behavior.

\section{MATERIAL AND METHODS}

A scanning microscope study of stridulatory setae 
morphology was done on a male and a female of $A$. suina from Canelones, Uruguay.

For the experimental study, spiders were collected in Melilla, Montevideo, and in several sites in Canelones, Uruguay. Males were collected during a short period of time (ends of February - first days of March 2004), immediately they reached adulthood at the field (PÉREZ-Miles et al., 2005). Females were maintained in the laboratory at least from one year before, allowing us to know their previous reproductive status (usually, they molt one time per year). Spiders were raised in glass jars of $7.5 \mathrm{~cm}$ diameter with soil as substrate and water provision. They were fed ad libitum on cockroaches, Blaptica dubia (Serville, 1839) (Blaberidae). Hairs were removed by rubbing with a scalpel against the spider immobilized by hand.

In a first experimental group, hairs and setae on the retrolateral face of palpal trochanter and prolateral face of the trochanter of leg I of five males and five females, were experimentally removed (shaved spiders). In other five males and five females, hairs and setae of an area of similar size on the retrolateral face of the proximal palpal femora and prolateral face of the proximal femora I, were also removed (control spiders). These 20 individuals were used in two series of experiments. Females were both recently and norecently molted, and they were randomly selected for the trials. In each series, five trials were done with shaved males and females; five with control males and females; five with shaved males and control females; and five with control males and shaved females. Experiments were carried out simultaneously by four observers; pairs were arranged randomly, but avoiding the repetition of pairs. Individuals were reused at least $24 \mathrm{~h}$ after previous trial.

The first series was performed from March $16^{\text {th }}$ to $19^{\text {th }}, 2004$, at least 4 days after hair removal, and the second one took place from April $13^{\text {th }}$ to $15^{\text {th }}, 2004$, at least 32 days after hair removal. In the second series, the pairs of individuals were different from the first series. First and second series totalized 40 trials.

In a second group other individuals were used, taking into account the results from the first group. Five males were shaved only in the retrolateral face of palpal trochanter (shaved spiders), and five males were shaved only in the retrolateral face of the proximal palpal femora (control spiders). Ten normal (not shaved), recently molted and unmated females were used in this group. Ten trials with shaved males and ten with control males were made. The same criteria for combinations and reuse of individuals applied in the first group, were followed.

All trials were carried out in glass cages of $30 \times 15 \mathrm{~cm}$ base and $20 \mathrm{~cm}$ height, with a layer of soil $7 \mathrm{~cm}$ deep and water provision. We excavated a burrow in each cage similar to the natural one (PÉREZ-MiLEs et al., 2005) against the glass wall, allowing the observation inside the burrow. Each female was placed at least $24 \mathrm{~h}$ before the trial.

Observations were initiated by carefully depositing the male as far as possible from the burrow entrance; behaviors were registered by notes since the first sexual behavior of male to at least $30 \mathrm{~min}$. If copulation took place, the observation was followed until the copulation ended. Registered behaviors were: body vibrations, palpal drumming, walking, resting (for males); leg tapping, walking, emergence from burrow (for females), and mating (for couple). Latency for female response by leg tapping was also registered. Female leg tapping was used as indicator of female receptivity.

Voucher specimens were deposited in the arachnological collection of the School of Sciences, Montevideo.

Data were analyzed to decide the use of parametric or non-parametric tests. In order to compare two samples of frequencies, we used the Fisher exact probability test, and the Mann-Whitney U-test for mean values. For comparing more than two samples, we used Chi-square and Kruskall-Wallis tests for frequencies and mean values, respectively. All statistical analyses were made using the PAST package, version 1.18 (HAMMER et al., 2003).

\section{RESULTS}

Setae morphology. Two types of setae were found in the retrolateral face of palpal trochanter: claviform and plumose setae. In the female, 28-30 claviform barbed setae were observed, as well as numerous plumose setae (Figs. 1, 2). The claviform setae are $800 \mu$ length and $100 \mu$ width (including barbs); their barbs are approximately $60 \mu$ length and the axis $1 \mu$ width. The plumose setae are longer $(1000-1500 \mu)$, thin and barbed; the setae including barbs is $10 \mu$ width; barbs are $10 \mu$ length. Male has the same type of hairs, but the claviform setae are fewer (20-24).

Prolateral face of leg I. Males and females of $A$. suina present three types of setae: claviform and plumose setae, similar to those found in the palpal trochanter, and spiniform setae (Fig. 3). Claviform setae are fewer than those on the palpal trochanter. The spiniform setae are $900 \mu$ length and $30 \mu$ width, and they have rows of short and strong conical barbs (Fig. 4) with curved tip.

Experiments. All males started sexual behavior soon after they were deposited on the soil with female threads. They displayed body vibrations (caused by the third pair of legs) alternated with walking. Males usually also performed frequent palpal drumming near the burrow entrance. Receptive female response consisted in rapid bouts of foreleg tapping against the substrate (leg tapping). Non-receptive females maintained resting inside the burrow. Mating took place outside the burrow, at the entrance. One or two palpal insertions were observed in each copulation. No cannibalism occurred.

Both shaved and control females responded and emerged from the burrow, but only control females copulated (one female with a control male and three with shaved males) (Tab. I). Similar experiments between first and second series from both experimental groups (i.e. shaved males/shaved females from first 


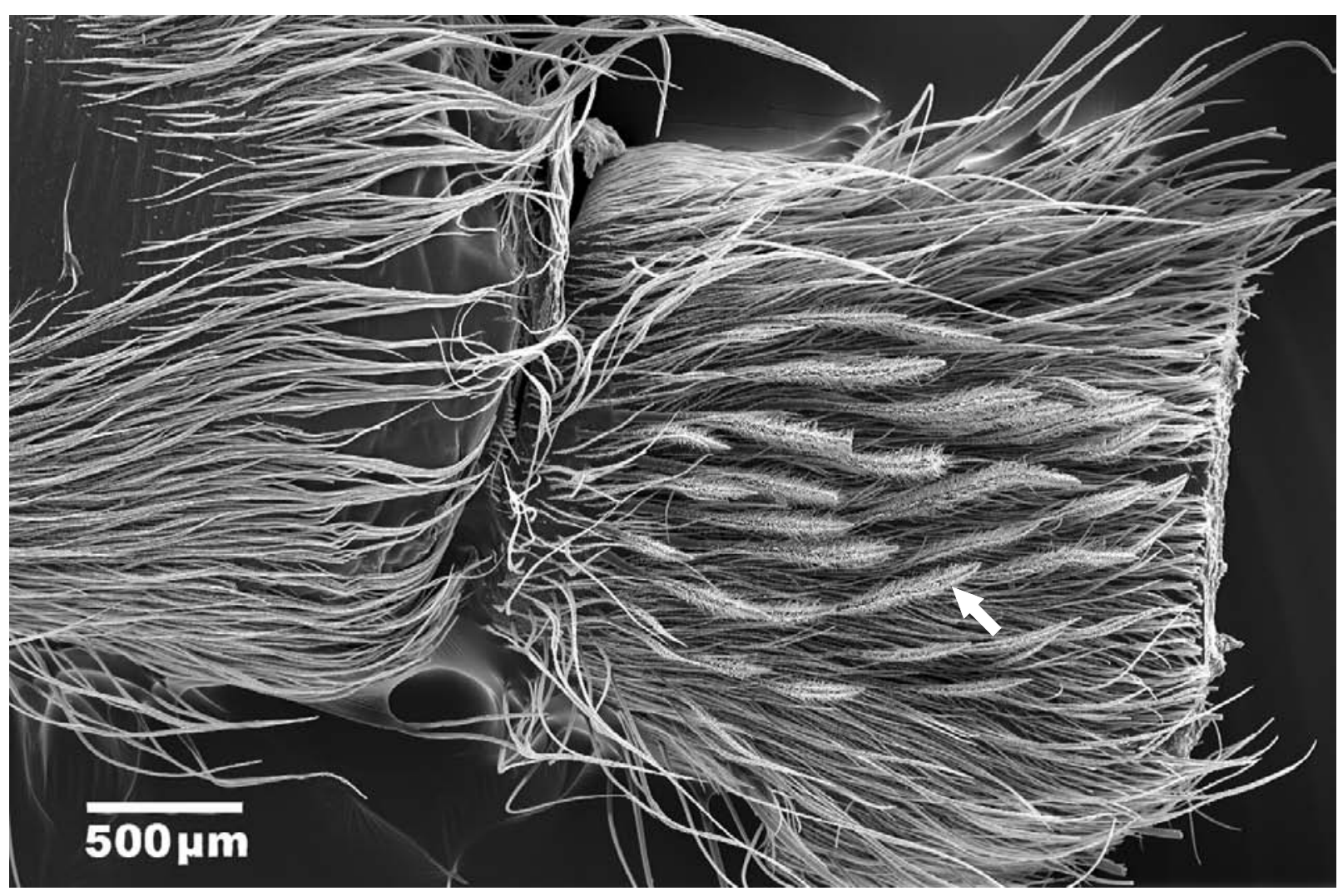

Fig. 1. Retrolateral face of palpal trochanter in a female Acanthoscurria suina Pocock, 1903, showing the arrangement of the specialized claviform setae (arrow).

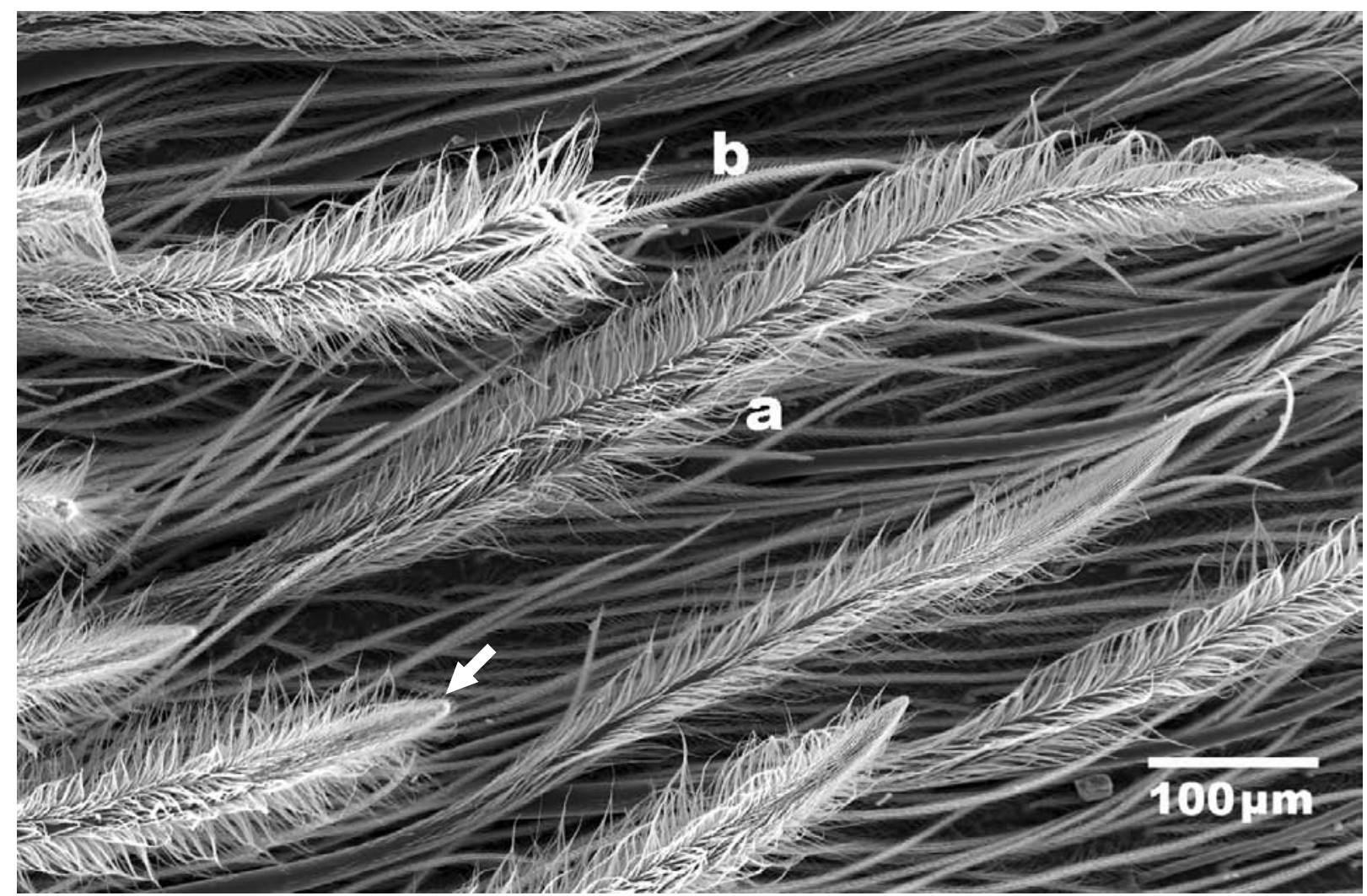

Fig. 2. A close-up of the retrolateral palpal trochanter of Acanthoscurria suina Pocock, 1903, showing the gross claviform (a) and the thin plumose (b) setae. Note the apical region of the claviform setae lacking barbs (arrow). 


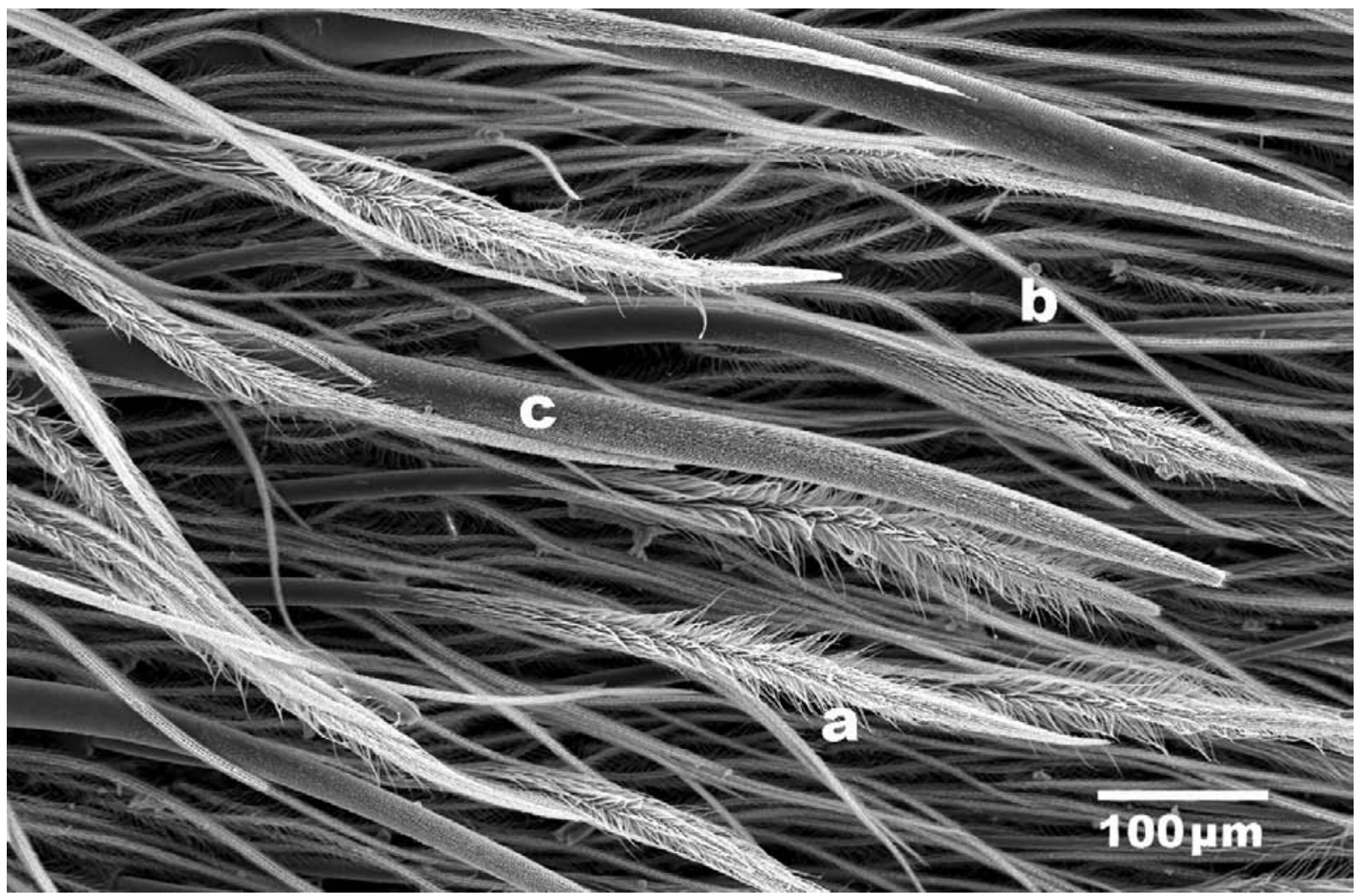

Fig. 3. A close-up of the prolateral face of foreleg trochanter of Acanthoscurria suina Pocock, 1903, showing the three types of setae: a) claviform, b) plumose and c) spiniform.

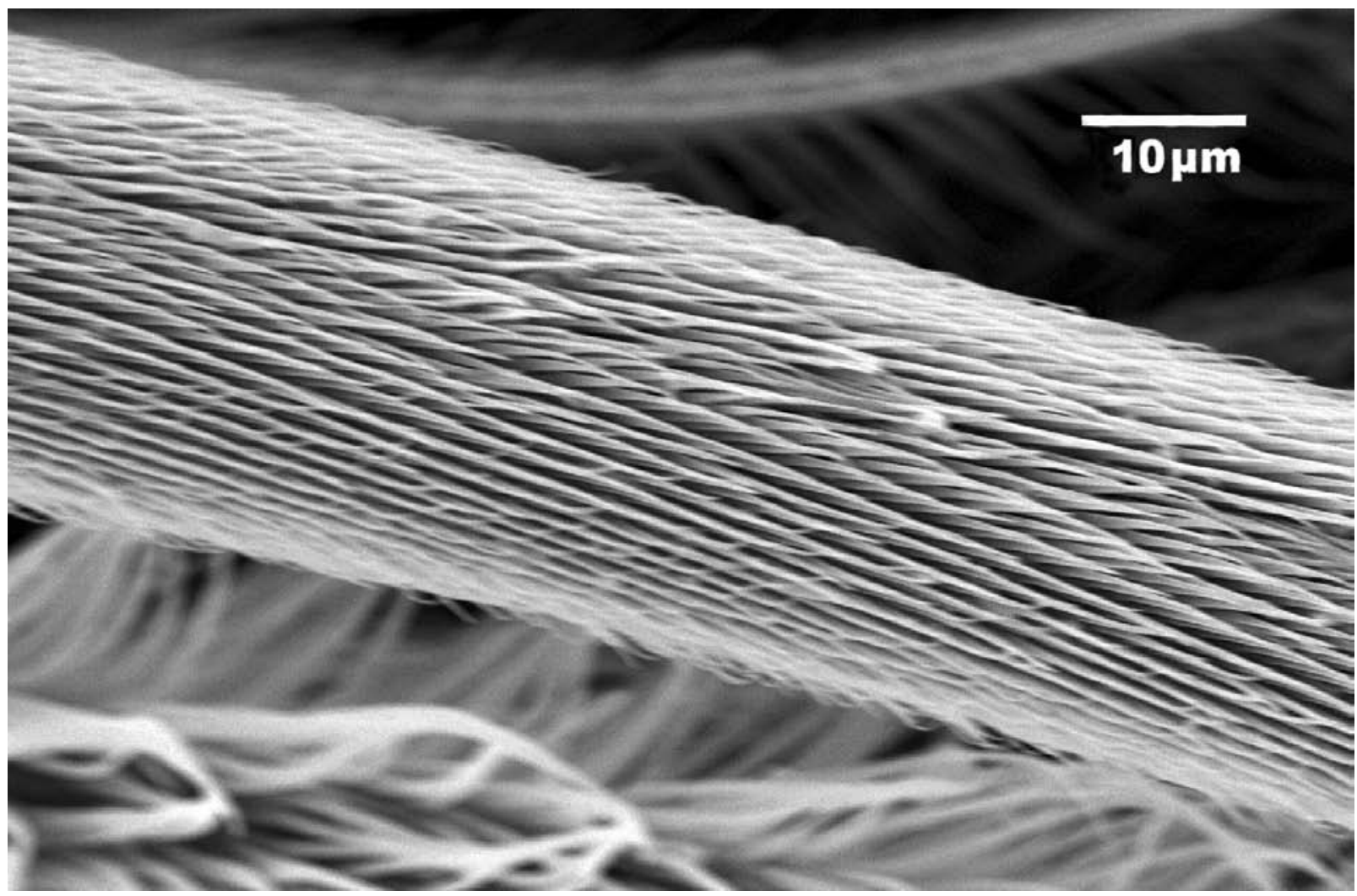

Fig. 4. A close-up of a spiniform seta of Acanthoscurria suina Pocock, 1903, showing the arrangement of short curved barbs. 
and second series of Group I), did not show significant statistical differences in any studied variable (Tab. II). No differences were found in female characteristics among experiments within the first series as well as within the second series (Tab. III). No differences were also found in Group II when compared experiments involving shaved and control males (Tab. III).

By grouping the results, we found that in Group
I, shaved males mated in three trials and elicited the same number of responses (11) as control males, which mated in one trial. Shaved females responded eight times in 20 trials and did not mate and control females responded 14 times in 20 trials and mated in four trials. In Group II (normal females), shaved males elicited one female response and did not mate. Control males elicited three responses and mated in one case.

Table I. Results from trials of sexual encounters of both series of the two experimental groups of Acanthoscurria suina Pocock 1903. Means are given as mean values \pm standard deviations (M, males; F, females).

\begin{tabular}{|c|c|c|c|c|c|c|}
\hline & Trials & $\begin{array}{c}\mathrm{N}^{\circ} \text { of females } \\
\text { displaying response }\end{array}$ & $\begin{array}{l}\text { Mean of latency } \\
\text { in response }(\mathrm{min})\end{array}$ & $\begin{array}{l}\text { Mean } \mathrm{N}^{\circ} \text { of bouts } \\
\text { of female response }\end{array}$ & $\begin{array}{l}\mathrm{N}^{\circ} \text { of females } \\
\text { that emerged }\end{array}$ & $\begin{array}{l}\mathrm{N}^{\circ} \text { of } \\
\text { mating }\end{array}$ \\
\hline \multicolumn{7}{|l|}{ Group I } \\
\hline \multicolumn{7}{|l|}{ First Series } \\
\hline Shaved M / Shaved F & 5 & 1 & 9.1 & 17 & 1 & 0 \\
\hline Control M / Control F & 5 & 4 & $9.9 \pm 7.4$ & $3.3 \pm 3.9$ & 1 & 1 \\
\hline Shaved M / Control F & 5 & 4 & $7.9 \pm 4.3$ & $7.3 \pm 1.5$ & 2 & 2 \\
\hline $\begin{array}{l}\text { Control M / Shaved F } \\
\text { Second series }\end{array}$ & 5 & 2 & $2.9 \pm 1.6$ & $6.0 \pm 4.2$ & 1 & 0 \\
\hline Shaved M / Shaved F & 5 & 3 & $11.1 \pm 10.7$ & $4.7 \pm 4.7$ & 0 & 0 \\
\hline Control M / Control F & 5 & 3 & $8.5 \pm 8.6$ & $4.7 \pm 5.5$ & 0 & 0 \\
\hline Shaved M / Control F & 5 & 3 & $6.3 \pm 4.4$ & $4.3 \pm 3.2$ & 1 & 1 \\
\hline Control M / Shaved F & 5 & 2 & $11.0 \pm 7.6$ & $4.0 \pm 4.2$ & 0 & 0 \\
\hline \multicolumn{7}{|l|}{ Group II } \\
\hline Shaved M / Normal F & 5 & 0 & 0 & 0 & 0 & 0 \\
\hline $\begin{array}{l}\text { Control M / Normal F } \\
\text { Second Series }\end{array}$ & 5 & 2 & $17.2 \pm 9.6$ & $18.5 \pm 23.3$ & 2 & 1 \\
\hline Shaved M / Normal F & 5 & 1 & 14.5 & 6 & 0 & 0 \\
\hline Control M / Normal F & 5 & 1 & 28.0 & 2 & 0 & 0 \\
\hline
\end{tabular}

Table II. Comparisons between similar experiments from both series into each experimental group using the Fisher exact probability test (P) for frequencies and the Mann-Whitney U-test (U) for mean values (S, shaved; C, control; N, normal; male/female).

\begin{tabular}{|c|c|c|c|c|c|c|c|}
\hline & Female response & Female & latency & Femal & bouts & Female emergence & Mating \\
\hline \multicolumn{8}{|c|}{ Group I } \\
\hline $\mathrm{S} / \mathrm{S}$ & $\mathrm{P}=0.238$ & $\mathrm{U}=0.000$ & $\mathrm{P}=1.000$ & $\mathrm{U}=0.000$ & $\mathrm{P}=1.000$ & $P=0.489$ & $\mathrm{P}=1.000$ \\
\hline $\mathrm{C} / \mathrm{C}$ & $P=0.417$ & $\mathrm{U}=5.000$ & $P=0.724$ & $\mathrm{U}=4.500$ & $P=0.596$ & $P=0.489$ & $\mathrm{P}=0.489$ \\
\hline $\mathrm{S} / \mathrm{C}$ & $P=0.417$ & $\mathrm{U}=5.000$ & $P=0.724$ & $\mathrm{U}=2.500$ & $P=0.216$ & $P=0.417$ & $P=0.417$ \\
\hline $\mathrm{C} / \mathrm{S}$ & $P=0.476$ & $\mathrm{U}=0.000$ & $P=0.121$ & $\mathrm{U}=1.000$ & $P=0.439$ & $\mathrm{P}=0.489$ & $\mathrm{P}=1.000$ \\
\hline \multicolumn{8}{|c|}{ Group II } \\
\hline $\mathrm{S} / \mathrm{N}$ & $P=0.489$ & $\mathrm{U}=0.000$ & $\mathrm{P}=1.000$ & $\mathrm{U}=0.000$ & $\mathrm{P}=1.000$ & $\mathrm{P}=1.000$ & $\mathrm{P}=1.000$ \\
\hline $\mathrm{C} / \mathrm{N}$ & $P=0.417$ & $\mathrm{U}=0.000$ & $\mathrm{P}=1.000$ & $\mathrm{U}=0.000$ & $\mathrm{P}=1.000$ & $\mathrm{P}=0.222$ & $P=0.489$ \\
\hline
\end{tabular}

Table III. Comparisons among data from encounters within each series of Group I, using Chi-square test $\left(\chi^{2}\right)$ for frequencies and Kruskal-Wallis test $(\mathrm{H})$ for mean values. For Group II, comparisons were made between data into first and into second series; frequencies using Fisher exact probability test (P) and mean values using the Mann-Whitney U-test (U).

\begin{tabular}{lccccc}
\hline & Female response & Female latency & Female bouts & Female emergence & Mating \\
\hline Group I & & & & & \\
First series & $\chi^{2}=5.46, \mathrm{P}>0.10$ & $\mathrm{H}=3.57, \mathrm{P}=0.31$ & $\mathrm{H}=4.22, \mathrm{P}=0.24$ & $\chi^{2}=0.80, \mathrm{P}>0.80$ & $\chi^{2}=4.31, \mathrm{P}>0.10$ \\
$\begin{array}{l}\text { Second series } \\
\text { Group II }\end{array}$ & $\chi^{2}=0.61, \mathrm{P}>0.80$ & $\mathrm{H}=0.61, \mathrm{P}=0.90$ & $\mathrm{H}=0.33, \mathrm{P}=0.96$ & $\chi^{2}=3.16, \mathrm{P}>0.30$ & $\chi^{2}=3.16, \mathrm{P}>0.30$ \\
First series & $\mathrm{P}=0.222$ & $\mathrm{U}=0.000 \quad \mathrm{P}=1.000$ & $\mathrm{U}=0.000 \quad \mathrm{P}=1.000$ & $\mathrm{P}=0.222$ & $\mathrm{P}=0.489$ \\
Second series & $\mathrm{P}=1.000$ & $\mathrm{U}=0.000 \quad \mathrm{P}=1.000$ & $\mathrm{U}=0.000 \quad \mathrm{P}=1.000$ & $\mathrm{P}=1.000$ & $\mathrm{P}=1.000$ \\
\hline
\end{tabular}




\section{DISCUSSION}

If stridulation occurs by rubbing of trochanters of palp against leg I, only claviform and spiniform setae would be involved in this mechanism, considering their strong appearance and structure. Plumose setae seem to be not related with stridulation due to their weak structure. The stridulatory setae found by MARSHALL et al. (1995) in femora of palps and legs of Theraphosa blondi (Latreille, 1804) resemble claviform setae in $A$. suina but in this species the area covered by barbs is more extended. The spiniform setae resemble in their whole extension the apical part of both claviform setae described here and stridulatory setae described by Marshall et al. (1995).

In general, two functions were proposed for spider stridulation: defense and sexual communication (Legendre, 1963; Uetz \& STRATton, 1982). The function of called stridulatory setae was tested for few species of theraphosids as involved in sound production. Marshall et al. (1995) indicated audible sound production in $T$. blondi in a context of defensive behavior. These authors first experimentally demonstrated that this sound is produced by stridulation, by remotion of femora setae. With the exception of $T$. blondi, the function of called stridulatory setae in signal production remains unknown in Theraphosidae. Also the behavioral situation where stridulation is involved, is mostly ignored.

In this paper, we did not find evidence of an important sexual role of stridulatory setae in A. suina. All our results were coincident in no detrimental action of setae ablation on male sexual attractiveness in all phases of courtship and mating, measured by female behavior. Shaved males elicited receptive female responses, in exactly the same proportion than control males (eleven in twice trials), and showed more copulatory success than control males (3 and 1, respectively) in Group I. Control females showed more receptive calls (in absolute numbers) than shaved females in Group I, but this tendency was inverted in Group II. Also, female shaving did not affect male and/or couple behavior. The specialized structure and location of these setae clearly suggest stridulation, but not related with sexual behavior.

No differences were detected between first and second series of experiments, suggesting no major influence of previous experience. Previous data (PÉREZMiLES et al., 2005) indicate that both female and mainly males remated in a short time period in the field. Then, reused individuals are not expected to behave in a different manner, and they can be used in consecutive experiments. In general terms, female receptiveness was low in relation to the reported by QUIRICI \& COSTA (2005), possibly caused by the advanced time when experiments were made respect to the narrow breeding season of the species. Moreover, spiders tested in group II (used after all trials of Group I were completed) were near of the end of this period, and sexual behavior could be negatively affected in both females (end of receptive period) and males (old males).

The occurrence of stridulatory setae in both adult male and female, as well as large juveniles, suggests a defensive function. Acanthoscurria suina presents a conspicuous defensive display potentially elicited by large predators (Pérez-Miles et al., 2005). This behavior consists in raising forelegs and palps, opening fangs, and shaking forwards and downwards these appendages. This last movement is compatible with the hypothesis of defensive stridulation during this display, because the involved structures could rub between them. Coincidently, these setae are absent in Eupalaestrus weijenberghi (Thorell, 1894), a sympatric and synchronous tarantula similar in size and ecologically to A. suina, but with an inverse, abdominal defensive display (PÉREZ-Miles et al., 2005).

Another possible interpretation of the stridulation is a defense against the pompilid wasps. Acanthoscurria suina is frequently attacked by the wasp Pepsis cupripennis Taschenberg, 1869 and the spider lack a defensive tube in her burrow as E. weijenberghi (COSTA et al., 2004). Stridulating setae only occur in large juveniles and adults, the sizes attacked by wasps. The mechanisms through which the stridulation could avoid wasps attacks, remain obscure.

\section{REFERENCES}

Chrysanthus, F. 1953. Hearing and stridulation in spiders. Tijdschrift voor Entomologie 96:57-83.

Costa, F. G.; Pérez-Miles, F. \& Mignone, A. 2004. Pompilid wasp interactions with burrowing tarantulas: Pepsis cupripennis versus Eupalaestrus weijenberghi and Acanthoscurria suina (Araneae, Theraphosidae). Studies on Neotropical Fauna and Environment 39(1):37-43.

Hammer, Ø.; Harper, D. A. T. \& Ryan, P. D. 2003. PAST Palaeontological Statistics, Version 1.18. Available at <http://folk.uio.no/ohammer/past>. Access in: 09.2004.

Legendre, R. 1963. L'audition et l'émission de sons chez les Aranéides. L' Année Biologique 2:371-390.

Marshall, S. D.; Thoms, E. M. \& Uetz, G. W. 1995. Setal entanglement: an undescribed method of stridulation by a neotropical tarantula (Araneae: Theraphosidae). Journal of Zoology 235:587-595.

Pérez-Miles, F.; Costa, F. G.; Toscano-Gadea, C. \& Mignone, A. 2005. Ecology and behaviour of the "road tarantulas" Eupalaestrus weijenberghi and Acanthoscurria suina (Araneae, Theraphosidae) from Uruguay. Journal of Natural History 39(6):483-498.

Pérez-Miles, F.; Lucas, S. M.; Silva, P. I. da \& Bertani, R. 1996. Systematic revision and cladistic analysis of Theraphosinae (Araneae: Theraphosidae). Mygalomorph 1(3):33-68.

Pocock, R. I. 1895a. Musical boxes in spiders. Natural Science 6: $44-50$

$1895 \mathrm{~b}$. On a new sound-producing organ in a spider Annals and Magazine of Natural History 16:230-233. 1897. On the spiders of the suborder Mygalomorphae from the Ethiopian Region contained in the collection of the British Museum. Proceedings of the Zoological Society 1897:724-774

1899. A new stridulating theraphosid spider from South America. Annals and Magazine of Natural History 3(13):347-349.

Quirici, V. \& Costa, F. G. 2003. Seismic communication during courtship in two burrowing tarantula spiders. In: Contributions to the XXVIII International Ethological Conference, Florianópolis, Brazil, 2003. Revista de Etologia 5 (suplemento): 195

2005. Seismic communication during courtship in two burrowing tarantula spiders: an experimental study on Eupalaestrus weijenberghi and Acanthoscurria suina. Journal of Arachnology 33(1):159-166. 
Schiapelli, R. D. \& Gerschman, B. S. 1964. El género Acanthoscurria Ausserer, 1871 (Araneae, Theraphosidae) en la Argentina. Physis 24(68):391-417.

Schmidt, G. 1999. Eine Klassifizierung der Stridulationsorgane. Mitteilungen bei der Deutschen Arachnologischen Gesellschaft $4(4): 3-5$.

. 2000. Zur Klassifizierung der Stridulationsorgane bei Vogelspinnen (Araneae: Theraphosidae). Entomologische Zeitschrift 110(2):58-61.
Simon, E. 1903. Histoire Naturelle des Araignées. 2. Paris, Roret. p.669-1080.

Uetz, G. W. \& Stratton, G. E. 1982. Acoustic communication and reproductive isolation in spiders. In: WitT, P. N. \& Rovner, J. S. eds. Spider communication. Mechanisms and ecological significance. New Jersey, Princeton University. p.123-159.

Wood-Mason, J. 1876. On the gigantic stridulating spider. Annals and Magazine of Natural History 16:96. 